811.111'366.573

$81 ' 364$

https://doi.org/10.18485/sj.2018.23.1.21

МАЈА Р. КУЈУНЏИЋ*

Универзитет Источно Сарајево

Филозофски факултет Пале
Оригинални научни рад

Примљен: 04. 01. 2018.

Прихваћен: 29. 01. 2018.

\title{
КОГНИТИВНОСЕМАНТИЧКИ ПРИСТУП ПАСИВУ У ТЕОРИЈСКОМ ОКВИРУ КОНСТРУКЦИЈСКЕ ГРАМАТИКЕ
}

У савременој лингвистичкој литератури, као и у традиционалним граматикама, а потом и у трансформационо-генеративној граматици, пасивна конструкција је најчешће дефинисина у нераскидивом односу са њеним еквивалентом у активу, из којег се изводи на прецизно дефинисан начин. Овакво поимање пасива довело је до тога да су многе конструкције, које би по својој форми и значењу могле бити сматране примјерима пасива, једноставно занемарене јер немају своје директне еквиваленте у активу. Такав формалистички приступ граматичком опису синтаксичких структура модификује когнитивнолингвистичка теорија, која, за разлику од формалног, даје примат интеракцији синтаксичке, семантичке и прагматичке компоненте, па циљ овог рада јесте да скрене пажњу на могућности истраживања пасива које су засноване на поставкама когнитивних лингвистичких теорија јер би салгедавање пасива на тај начин ријешило питање свих оних неправедно запостављених конструкција обиљежених као „неправи” пасиви.

Кључне ријечи: пасив, формалистички приступ, трансформационо-генеративна граматика, когнитивносемантички приступ, конструкцијска граматика

"maja.kujundzic@ffuis.edu.ba 


\section{1. УВОД}

Од најранијих суочавања са пасивном конструкцијом, научени смо да је посматрамо и дефинишемо у нераскидивом односу са њеним еквивалентом у активу, из којег се изводи на начин који је веома прецизно дефинисан у граматикама. Сљедећи овакву логику посматрања пасивне конструкције, сасвим је природно да се, обрнутим процесом, од пасивне конструкције враћамо ка оној иницијалној, активној, при чему, као неку врсту бонуса добијамо могућност одлучивања о судбини вршиоца радње, чији идентитет, по сопственом нахођењу и потребама, можемо открити, или пак, једноставно изоставити.

Сматрамо да је управо овакво поимање пасива довело до тога да су многе конструкције, које би ипак по својој форми и значењу могле бити сматране примјерима пасива, једноставно занемарене јер немају своје директне еквиваленте у активу. Као посљедица оваквог приступа пасиву, такве конструкције су окарактерисане као примјери „неправих пасива”, као што су такозвани полупасиви и псеудопасиви, како и сами називи ових конструкција више него јасно сугеришу (Свартвик: 1966). Овдје би такође било занимљиво поменути нефинитне пасиве, који су из традиционалних разлога најчешће поптуно изостављени из већине описа пасивне конструкције. Наиме, помињање нефинитних пасива је у већини традиционалних граматика, а под њиховим утицајем и савремених граматика енглеског језика, сведено само на препознавање њиховог постојања, и то у секцијама које нису посвећене искључиво пасиву, него нефинитним глаголским облицима као што су инфинитив и герунд. Имајући ово у виду, а са циљем промовисања нефититних пасива из њихове маргинализоване позиције, из својих претходних истраживања о пасиву нисмо искључили нефинитне пассиве (в. Кујунџић 2016), чијим примјерима сматрамо оне конструкције чији се глаголски елемент састоји од нефинитног облика помоћног глагола to be или to get (-ing и инфинитив са to облици) и прошлог партиципа глагола и оне конструкције чији глаголски елемент чини само прошли партицип главног глагола. Будући да консултована литература није понудила јасну класификацију нефинитних пасива, сматрамо да је могуће успоставити је на основу функције зависне реченице у којој се јављају, па се на основу тога критеријума могу издвојити номиналне, прилошке и придјевске пасиве (Кујунџић 2016: 26).

Чак и оне ријетке студије које се противе наведеном виђењу пасивне конструкције, те је покушавају видјети као конструкцију која је већим дијелом независна од пасива, у суштини опет третирају и описују пасив на основу тога да ли, и у којој мјери, постоји извјесна трансформациона веза са њему одговарајућим еквивалентом у активу. Па тако Свартвик који је, могло би се рећи, један од првих граматичара који у свом капиталном дјелу о пасиву $O n$ Voice in English Verb (1966) покушава да изађе из устаљеног обрасца, те да 
пасивну конструкцију не види искључиво као инверзију одговарајућег јој еквивалента у активу, најприје истиче да пасив неће посматрати само као инверзију његовог одговарајућег облика у активу, него као конструкцију чије је постојање дјелимично независно од постојања његовог „еквивалента” у активу, те да ће у складу са тим његово истраживање обухватити све оне језичке структуре које значењем и формом наликују пасиву, али ипак немају своје директне еквиваленте у активу. Упркос томе, Свартвик отпочиње своје истраживање у великој мјери формално дефинисаном конструкцијом, па у складу са тим, што је контрадикторно иницијалној намјери, све оне језичке конструкције које формално у потпуности не наликују пасиву, чак иако су му семантички сличне, бивају маргинализованеи у његовом истраживања. Он не одбацује чињеницу да је обрнута процедура истраживања могућа, тј. кренути од значења и завршити формом, али истиче да је "more difficult to control it in the case of voice то (Свартвик 1966: 5). Даље, он сматра да је веома важно држати семантички и несемантички приступ колико год је могуће раздвојеним јер се форма и значење не подударају увијек и у вези са овим цитира Фриза, који каже да "not only do structures usually signal several different meanings, but what is more important, there is probably in present-day English no structural meaning that is not signalled by a variety of structures" (Фриз у Свартвику 1966: 5). Његово мишљење да значење може да произиђе из обрасца дистрибуције одређених језичких структура и на тај начин одреди њихово граматичко значење, засновано је на Пајковој тврдњи да:

\footnotetext{
...distributional characteristics which above all others allow the investigator to discover morphemic class in the first place, and to know that such classes are relevant to the language in question, whereas an attempt to make a class meaning a basic starting criterion for determining the classes is fatal to any structural analysis. (Пајк у Свартвику 1966: 5)
}

Свартвик такође објашњава неуспјех ранијих граматичара да се сложе у вези са тим шта чини пасив, као посљедицу чињенице да се њихове дефиниције обично односе на семантичке критерије који се могу појавити у форми која се не поклапа са формом у питању. У суштини Свартвик успоставља дијагностички кључ за препознавање и класификовање пасивних конструкција који се јавља у виду скале пасива у којој су анализиране пасивне конструкције поредане на основу њихове способности да буду трансформисане у свој еквивалент у активу (Свартвик 1966: 2). Како се креће ка дну скале пасива, поменути класификациони критериј слаби, па су у складу са тим:

[a]gentive clauses, at the top of the passive scale, are transformationally related to active clauses, whereas non-agentive clauses, at the bottom end of the passive scale, have syntagmatic affinity with active equative clauses. In between the two extremes of the scale there are intermediate clauses with mixed properties. (Свартвик 1966: 138)

Дакле у врху скале налазе се „прави” примјери пасива, док крећући се према дну скале наведене конструкције све више губе право на тај статус, 
па у складу са тим бивају маргинализоване и у већини случајава потпуно искључене из сваке врсте истраживања у овом контексту.

Слично потврђују Кверк и сарадници који, сасвим очигледно, своју скалу пасива (енг. passive gradient, 1985: 65) преузимају од Свартвика, па основни критериј на којем она почива јесте способност датих конструкција да буду трансформисане у своје еквиваленте у активу. Они, међутим, за „нетипичне” или „неправе” примјере пасива уводе нове називе, па називајући их, полупасивима (енг. semi-passives) и псеудопасивима (енг. pseudo-passives) додатно портврђују њихову оказионалност у поредјењу са правим пасивима (енг. central passives).

Дакле, пасивна конструкција је у већини случајаве посматрана кроз призму форме, док је питање значења занемарено, па су, у складу са тим, занемарене и све оне конструкције које би по свом значењу, али не и по форми, могле бити сматране примјерима пасивне конструкције. Разлог том преовладавајућем виђењу пасива у лингвистичкој литератури налазимо у чињеници да већина традиционалних граматика енглеског језика, те под њиховим утицајем и савремених анализа пасива виде ову конструкцију у уској вези са њеним еквивалентом у активу, тј. као облик изведен инверзијом из њој одговарајуће активне конструкције (в. Кујунџић 2015)

Надаље, овакав приступ опису пасивне конструкције који даје примат форми над значењем бива још дубље учвршћен 50-их година прошлог вијека, ступањем транформационо-генеративне граматике на лингвистичку сцену. Ова теорија, која засигурно јесте најутицајнија и најпознатија међу формалним приступима граматичком опису, од својих зачетака пасивну конструкцију узима као савршен примјер трансформације, чиме додатно доприноси њеном опису у нераскидивом односу са њеним еквивалентом у активу из којег се генерише процесом трансформације. Творац ове теорије Ноам Чомски у фокус граматичког описа ставља форму, јер сматра да значење не учествује у генерисању нових структура, односно да се актуализује тек по завршетку дјеловања синтаксичких механизама путем којих се производе граматички тачне реченице неког језика, које се тек накнадно семантички интерпретирају. Дакле значење има само интерпретативну улогу и с обзиром на то да је феномен који је подложан мноштву субјективних контекстуално условљених тумачења, не може се сматрати поузданим оквиром грамтичког описа и тумачења.

Непуну деценију након појаве The Syntactic Structures (1957), као револуционарног дјела Ноама Чомског, јављају се реакције на чињеницу да је значење запостављено у граматичком опису, па тако Фодор и Кац у свом дјелу The Structure of a Semantic Theory (1963) настоје да укључе сематничку компоненту у граматичко тумачење додјељујући свакој структури насталој у трансформационо-генеративном процесу одређену семантичку интерпетацију. 
Основне компоненте њихове семантичке теорије чине рјечник и пројекцијска правила, при чему, у случају када је структура добијена путем трансформационог-генеративног процеса неправилна, пројекцијска правила није могуће примијенити, што опет показује да је значењу ипак остављена само интерпретативна улога, те да примат и аутономност синтаксичке компоменте и даље остају неприкосновени.

Годину касније Кац и Постал (1964) редефинишу Кац-Фодорову теорију не придајући сменатичкој компоненти само „површинску” интерпретативну функцију, него тврдећи да семантичка компонета дјелује искључиво на све дубинске реченичне структуре при чему трансормације не утичу на значење. Кац и Постал на овај начин семанатичкој компоненти додјељују есенцијалну и дубинску улогу, за разлику од „површинске” и интерпретативне које су јој приписиване у ранијим приступима граматичком опису.

Под утицајем Каца и Постала, Чомски (1965) у своју иницијалну теорију, поред синтаксичке и фонолошке компоненете, укључује и семантичку, примјењујући је искључиво на дубинске структуре. Међутим, на основу бројних примјера испоставља се да семантичка компонента ипак мора бити повезана и са површинском структуром, па се тако и ова теорија, као и претходна, показују непотпуном. Чомски, дакле, у крајњој линији, остаје при становишту да значењска компонента дјелује на површинском нивоу и има искључивно интерпретативну улоге, те постаје предводник оне струје генеративних граматичара који заступају такозвану интерпретативну семантику када је у питању улога значења у граматичком опису.

Насупрот њима, формира се струја међу генеративним граматицарима који сматрају да семантичка компонента има великог удјела у процесима који се дешавају у дубинским структурама, тј. у трансформационо-генеративном процесу, па се стога сматрају представницима генеративне семантике. Може се рећи да су управо генеративни семантичари попут Лангакера и Лакофа били зачетници идеје функционалног приступа граматичком опису који, за разлику од формалног, који даје примат синтаксичкој компоненти, ставља акценат на граматички опис који почива на интеракцији синтаксичке, семантичке и прагматичке компоненте. Оваква рекација на формалне приступе у граматици добија своје темеље и надградњу у оквиру најутицајнијег и најпознатијег функционалног приступа граматичком опису познатог као когнитивна лингвистика.

С обзиром на то да су формални приступи граматичком опису, на челу са транформационо-генеративном граматиком, у огромној мјери формирали и учврстили преовладавајуће схватање пасива у савременој лингвистичкој литератури, те да је когнитивно лингвистичка теорија настала управо као рекција на формалне приступе граматичком опису, циљ овог рада јесте да кроз 
сажети приказ виђења пасива у оквиру когнитивне лингвистике послужи као инспирација за будућа истраживања о пасиву заснована управо на њеним поставкама. Надамо се да би овакво салгедавање пасива ријешило и интригантна питања свих оних неправедно запостављених конструкција обиљежених као „неправи” пасиви - у првом реду статус полупасива, псеудопасива и нефитних пасивних конструкција, а у исто вријеме и утицало на ревизију начина на који је пасивна конструкција представљена у савременим граматикам енглеског језика, а путем њих и у савременом школству.

С обзиром на то да обим овог рада не омогућава свеобухватнији приказ пасивне конструкције у оквиру когнитивне лингвистике, фокус анализе усмјерили смо на конструкцијску граматику која представља дио когнитивне лингвистике - дијелом због тога што су већина граматичара који се баве овим теоријама когнитивни лингвисти, а дијелом због тога што конструкцијска граматика почива на сличним, могло би се рећи истим теоријским и филозофским основама као и когнитивна лингвистика. У исто вријеме се надамо да ће овај сажети преглед виђења пасива из угла конструкцијске граматике, послужити као подстрек за сагледавање и анализу пасивне конструкције и из улга других грана когнитивне лингвистике.

\section{2. ПАСИВ ИЗ УГЛА КОГНИТИВНЕ ЛИНГВИСТИКЕ}

Когнитивна лингвистика заснива се се на три основне претпоставке: 1) језик није самостална когнитивна способност, већ је у уском односу са осталим когнитивним способностима и доменима знања, 2) граматика је концептуализација и 3) знање језика израста из његове употребе (Крофт и Круз 2004: 1). Језичке јединице се формирају апстраховањем, које је условљено употребом (Лангакер 1987), а према карактеру могу бити врло одређене или потпуно схематске. С обзиром на то да језичке јединице израстају из употребе, може се закључити да когнитивнолингвистички приступ језик сматра искуственом појавом, језичке јединице примарним и симболичким, а језичка правила схематским конструкцијама.

Како је језик интегрални дио когниције, Тејлор у своме дјелу Cognitive Grammar (2002) сматра да би било од користи навести неке од човјекових когнитивних способности које су уско везане за њега. С обзиром на то да је центар нашег истраживања пасивна конструкција, овом приликом ћемо поменути само оне аспекте когнитивнолингвистичке теорије који се директно тичу пасива. Наиме, у поприлично дугој листи наших когнитивних способности које су у уској вези са језиком издвојићемо когнитивну способност коју Тејлор назива организација лика и позадине (eng. figure-ground organization; Tејлор 2002: 10), јер се у оквиру ње помиње пасивна конструкција, што нам помаже 
да схватимо како је ова конструкција виђена из угла когнитивне лингвистике. Ова тема је нешто детаљније обрађена и од стране Талмија, који појмове лик и позадина дефинише на сљедећи начин:

The figure is a moving or conceptually movable entity whose site, path, or orientation is conceived as a variable the particular value of which is the relevant issue. The Ground is a reference entity, one that has a stationary setting relative to a reference frame, with respect to which the Figure's site, path, or orientation is characterized (Talmi 2001: 184).

Визуелна перцепција обезбјеђује прототип за организацију лика и позадине. Одређени аспекти визуелне сцене издвајају се из њене позадине. На примјер, док гледамо у ову страницу, примјећујемо црне знакове (лик) на бијелој позадини и готово је сигурно да је нећемо посматрати као комплексни бијели облик (лик) на фрагментираној црној позадини. Организација лика и позадине може бити примијењена и на друге облике чула, као, на примјер, у случају када чујемо глас једне особе у односу на неразговијетну буку у позадини. Организација лика и позадине је у веома уској вези са пажњом, јер се наша пажња природно и спонтано креће ка лику, тј. јер одређени елемент у позадини постаје лик управо због тога што је у фокусу наше пажње. У вези са овим можемо лако закључити да је организација лика и позадине у великој мјери флексибилна, јер промјеном фокуса наше пажње организујемо дату сцену на различите начине. Организација лика и позадине не односи се само на чулну перцепцију (била она визуелна или аудитивна) већ и на начин на који размишљамо о одређеној ситуацији односно на начин на који је концептуализујемо. Као таква, организација лика и позадине је круцијална и када је у питању лингвистичка семантика. Наиме, организација лика и позадине посебно се манифестује у начину на који је одређена сцена организована у сврху њеног лингвистичког израза. Као веома једноставан примјер могу нам послужити сљедеће реченице, за које би се могло рећи да обиљежавају у потпуности исти догађај, (Тејлор 2002: 11):

(1) The farmer shot the rabbit.

(2) The rabbit was shot by the farmer.

Међутим, (1) ставља фокус на оно што је фармер учинио, док је у случају (2) зец лик и у фокусу је оно што се њему десило (Тејлор 2002: 11). На основу овога јасно је зашто смо посветили одређену пажњу објашњавању когнитивне способности организације лика и позадине, јер је она, као што смо видјели из датих примјера, битна за наше разумијевање виђења пасивне конструкције из угла когнитивне лингвистке.

Слично Тејлору, у свом опису семантичке структуре Лангакер разматра размјештај сцене користећи два кључна појма: лик првог плана (енг. trajector; Лангакер 1987: 120-122) или лик другог плана (енг. landmark, Лангакер 1987: $120,122)$, при чему као и Тејлор за примјер користи пасивну конструкцију. 
Гелдова (2002: 202), међутим, сматра да ако упоредимо Лангакеров опис са Тејлоровим, видјећемо да Лангакер ликове првог и другог плана не повезује са пажњом. „Он сматра да лик и позадина концептуално не зависе од средишта пажње (Крофт и Круз 2004: 58), док их Лангакер (1987: 121) везује за перспективу и сматра их темељним когнитивним функцијама заснованим на поређењу два елемента референтног призора, при којем се наш суд базира на контрасту" (Гелд, 2002: 202). За примјере узима сљедеће реченице (Табаковска у Гелдовој 2002: 202):

(3) Предсједник је примио посланика

(4) Посланик је примљен од стране предсједника.

Гелдова закључује да наведене реченице генеративна граматика сматра значењским еквивалентима изведеним на основу структурних трансформација. Насупрот томе, когнитивна граматика их сматра значењски различитим, а разлику објашњава тиме који је лик у призору истакнут. Граматички субјекат је лик првог плана истакнут из позадине коју чини остатак реченице.Објекат је лик другог плана и елемент наведене позадине.

\section{1. Пасив из угла конструкцијске граматике}

Да бисмо видјели како је пасивна конструкција виђена из угла конструкцијске граматике, користићемо се сљедећим граматичким теоријама или моделима: когнитивном граматиком и радикалном конструкцијском граматиком. Двије наведене теорије спадају у породицу граматичких теорија коју називамо конструкцијском граматиком, која опет представља дио когнитивне лингвистике, те једну од њених теорија.

\subsection{1. Когнитивна граматика}

Когнитивна граматика не види пасив као конструкцију изведену из одређене дубинске структуре путем помјерања постглаголске именичке фразе у позицију субјекта, као што то чини трансформативно-генеративна граматика. Когнитивна граматика је оријентисана на површину. Апстрактни ентитети су прихватљиви у оној мјери у којој могу послужити као схематски обрасци за одређене структуре које су у стварној употреби и које могу бити апстраховане из њихових примјера у употреби. На примјер, дубинске структуре које су у раскораку са површинским у смислу њихових саставних дијелова и слиједа у којем се појављују у њима, посматрају се са великим скептицизмом. Према Лангакеру:

Cognitive grammar claims that grammatical structure is almost entirely overt. Surface grammatical from does not conceal a 'truer', deeper level of grammatical organization; rather it itself embodies the conventional means a language employs for rhe structuring and symbolization of semantic content. (Langaker u Tejloru 2002: 28) 
У складу са овим Тејлор тврди како би било неприхватљиво за когнитивну граматику да анализира пасивну реченицу као што је The jewels were stolen као изведену из дубинске структуре путем помјерања именичке фразе the jewels из постглаголске позиције у позицију субјекта. Наиме, дубинска структура се не слаже са пасивним конструкцијама са којима се сусрећемо у стварној употреби. Она није садржана у самом пасиву, па стога и не може бити апстрахована путем генерализације засноване на примјерима из његове стварне употребе (Тејлор 2002: 28).

За разлику од трансформационо-генеративне граматике, која ставља акценат на синтаксу као централну лингвистичку тему, когнитивна граматика сматра да би синтаксички и семантични ниво лингвистичког истраживања требало да буду уско повезани. У вези са овим, когнитивна граматика сматра да и синтаксички обрасци имају одређено значење и види семантичке факторе као мотивацијску силу за синтаксичке конвенције у језику, тј. она заступа мишљење да "formal aspects of an expression can be fully predicted from, and are fully determined by, its semantics" (Тејлор 2002: 29). У вези са овим није изненађујуће да Лангакер (1982) види пасивну конструкцију представљену са „be + партицип прошли” као мотивисану од стране својих саставних дијелова. И не само то, он сматра да и сам образац који повезује ове компоненте има значење. Тако се може уочити да према когнитивној граматици свака морфема у пасиву има значење које произлази из осталих употреба ових граматичких морфема. У вези са овим могло би се закључити да основно обиљежје пасива, тј. чињеница да је лик првог плана поистовјећен са ликом другог плана, може бити приписано значењу пасивне варијанте морфеме прошлог партиципа $(-e d)$. Због тога пасивни партицип сигнализује распоред лик првог плана/лик другог плана независно од његовог појављивања у клаузи. Међутим, пасивни партицип не посједује временску димензију и због тога захтијева асистенцију помоћног глагола to be. На овај начин добијамо конструкцију у којој лик првог плана активне реченице постаје лик другог плана пасивне реченице, док оно што је имало улогу лика првог плана у активној реченици може бити изостављено или претпостављено из контекста.

Тејлор (2002) такође помиње пасив у поглављу о темпоралним или временским профилима. Реченица The picture was above the sofa (Тејлор, 2002: 211) профилира (енг. profile) темпорални однос који обухвата временски период који је дио профила овог исказа. Овај однос је такође статичан, тј. не мијења се у временском периоду профилираном у датом исказу. Ове аспекте наведеног исказа, према Тејлору, приписујемо природи глагола то бе, који у већини случајева профилира статични однос, па га он стога узима као представника, тј. као схематску основу за цијелу групу статичних глагола, као што cy resemble, hate, lie. Овдје се, међутим, покреће питање помоћног глагола to $b e$ у пасиву јер би примјер дат од стране Тејлора могао бити прочитан на два 
различита начина, од којих један није статичан, већ процесуалан. Примјер је сљедећи: (Тејлор 2002: 211):

(5) This watch was stolen.

Према Тејлору, ова реченица може бити прочитана као This was a stolen watch ili This watch was stolen (at the airport) (Тејлор 2002: 211). Очигледно је да је прво читање статично, док је друго процесуално. Занимљиво је видјети како когнитивна граматика види и интерпретира пасив, јер, као што смо управо видјели, она омогућава двије интерпретације пасива, од којих је само друга виђена као примјер пасивне конструкције. У вези са овим, могли бисмо закључити да, у складу са когнитивном граматиком, пасивом можемо сматрати само ону конструкцију у којој глагол to be профилира процесулани однос.

Тејлор даље помиње пасив у секцији о номиналним елементима који немају улогу директних партиципаната у датој радњи. Иако су партиципанти радње најчешће номинални елементи представљени именичком фразом, дешава се такође да номинални елементи немају увијек такву улогу. Такви номинални елементи могу имати статус предикатских придјева и пасив може послужити као тест за то да ли ови номинални елементи имају улогу партиципаната у датој радњи или не. Ово нам такође говори више о природи пасива јер показује да номинални елементи који немају улогу предмета радње не могу заузети позицију субјекта у пасивној реченици, као што је приказано у сљедећим примјерима (Тејлор 2002: 418):

(6) The book costs $£ 50$.

(7) $£ 50$ is cost by this book

Очигледно је да реченица (6) не може бити претворена у пасив јер њен други номинални елемент нема улогу партиципанта у датој радњи или процесу. Пасив се затим помиње у секцији о клаузама са три партиципанта. Ти партиципанти су сљедећи: агенс, ствар која подлијеже промјени и особа или институција која бенефицира (има корист) од те промјене. Ова три партиципанта могу бити поредана различито, што ће утицати на то шта ће бити субјекат пасивне реченице. У случају када је бенефактив (енг. beneficiary) учињен пацијенсом радње, он ће бити субјекат пасивне реченице и у том случају сва три партиципанта морају бити поменута. У другу руку, ако је ствар која подлијеже промјени учињена пацијенсом, онда ће она постати субјекат пасивне реченице, али у овом случају корисник се појављује као дио препозицијске фразе и његово појављивање није увијек обавезно. Тејлор у слиједећим реченицама демонстрира различите начине редања трију партиципаната (Тејлор 2002: 426):

(8) I'll mail you the report.

(9) I'll mail the report to you. 
(8a) You will be mailed the report.

(9a) The report will be mailed (to you).

Било би такође интересантно погледати примјере које Тејлор користи за транзитивне клаузе у којима субјекатски номинални елемент одређује локацију (Тејлор 2002: 576).

(10)The tent sleeps six

(11) The fifth day saw our departure.

Овакве клаузе су идиоматске јер су ограничене кад су у питању елементи који могу заузети позицију субјекта, али оно што је интересантно јесте чињеница да ове, за разлику од регуларних транзитивних клауза, не могу бити претворене у пасивне конструкције.

\subsection{2. Радикална конструкцијска граматика}

Сем когнитивне граматике, у новије вријеме пасив је предмет проучавња и у оквиру радикалне конструкцијске граматике (енг. Radical Construction Grammar). У своме дјелу Cognitive Linguistics (2004), Крофт и Круз користе управо пасивну конструкцију како би објаснили основне постулате ове граматичке теорије. Радикална конструкцијска граматика се бави интерном структуром конструкција и сматра да конструкције нису изведене из њихових дијелова, него су дијелови изведени из конструкција у којима се појављују. У вези са овим може се рећи да ова теорија у многоме сличи гешталт теорији. Радикална конструкцијска граматика се разликује од конструкцијске граматике по томе што дефинише однос између елемената у конструкцији искључиво на семантичкој основи, тачније речено, у радикалној конструкцијској граматици не постоје синтаксички односи. Ова граматичка теорија сматра да синтаксички односи између елемената нису неопходни, гледано из угла разумијевања језика у конструкцијској граматици. (Крофт и Круз 2004: 287). Наиме, у радикалној конструкцијској граматици морфосинтаксички елементи који нам служе за одређивање синтаксичких односа у другим теоријама представљају симболичке везе између фонолошког и семантичког нивоа одређене конструкције. Морфосинтаксички елементи који наводно указују на синтаксичке односе помажу слушаоцу да идентификује улогу коју елементи у тој конструкцији заузимају у значењу те конструкције као цјелине (Крофт 2004: 233-236). Такође, комбинација морфосинтаксичких елемената у одређеном исказу посматраном као цјелина помаже слушаоцу да идентификује конструкцију (Крофт 2004: 236-37). Као примјер за те тврдње Крофт и Круз (2004: 286) узимају гешталт комбинацију помоћног глагола $b e$, прошлог партиципа глагола и приједлога $b y$, који у синтаксичкој комбинацији са субјекатском фразом, глаголом и косим падежом (енг. oblique) јасно идентификује пасивну 
конструкцију, док индивидуални елементи идентификују радњу (флективни глагол и позиција послије помоћног глагола), агенс (by са косим падежом) и пацијенс (субјекатска позиција). Као закључак, аутори истичу сљедеће: "[i]n other words, the syntactic properties that seemingly encode syntactic relations in fact encode symbolyic relations, between individual elements and components of the construction and between the constructional form as a whole and its meaning." (Крофт и Круз 2004: 286)

У закључку овог поглавља можемо рећи да смо се, да бисмо видјели како је пасивна конструкција виђена из угла конструкцијске граматике, користили сљедећим граматичким теоријама или моделима: когнитивном граматиком и радикалном конструкцијском граматиком. Двије наведене теорије спадају у породицу граматичких теорија коју називамо конструкцијском граматиком и која представља дио когнитивне лингвистике - дијелом због тога јер су већина граматичара који се баве овим теоријама когнитивни лингвисти, а дијелом због тога што конструкцијска граматика почива на сличним, могло би се рећи истим теоријским и филозофским основама као и когнитивна лингвистика. Више је него очигледно да обје граматичке теорије примарном граматичком јединицом не сматрају атомску синтаксичку јединицу и правила њеног комбиновања, већ граматичку конструкцију у њеној цијелости, а граматику језика посматрају као скуп класификација конструкцијских породица. У конструкционој граматици, као у општој семиотици, граматичка конструкција представља спој форме и садржаја. Формални аспекат конструкције је обично описан као синтаксички образац, али форма покрива више од синтаксе јер такође укључује фонолошке аспекте као што су прозодија и интонација, док садржај укључује и семантичко и прагматичко значење. Семантичко значење граматичке конструкције састоји се од концептуалних структура постулираних у когнитивној семантици: представа - схема, оквира, концептуалне метафоре, концептуалне метонимије, прототипова различитих врста, менталног простора и различитих претапања и спајања наведених концепата, које називамо мјешавинама (енг. blends). Прагматика у овом случају постаје когнитивна семантика комуникације - модерна верзија Росове и Лејкофове перформативне хипотезе из 70-их година прослог вијека. Форма и садржај су према Лангакеру симболично повезани. Другим ријечима, граматичке конструкције, без обзира на њихову семантичку комплексност и структуру, представљају спој форме и значења. У складу са овим и ријечи представљају примјере конструкција. Штавише, конструкцијски граматичари тврде да су сви спојеви форме и значења конструкције, укључујући фразалне структуре, идиоме, ријечи, па чак и морфеме.

Из наведеног је сасвим јасно да конструкцијска граматика почива на схемама и класификацијама и не функционише користећи динамична деривацијска правила путем којих површинске структуре изводи из дубинских. У складу с тим, конструкцијски граматичари негирају конструкцијску полисеми- 
ју, што значи да сматрају да активна и пасивна верзија одређене пропозиције нису изведене из исте дубинске структуре него представљају примјере двију различитих конструкције. Друкчије речено, с обзиром на то да су конструкције спој форме и значења, активна и пасивна верзија исте пропозиције нису у односу синонимије јер се разликују по своме садржају (у овом случају по своме прагматичком садржају).

\section{3. ЗАКЉУЧАК}

Виђења пасивне конструкције из угла когнитивне лингвистке сугерише управо оно што је било речено у уводном дијелу овог рада. Наиме, за разлику од формалних приступа опису пасивне конструкције, на челу са трансформационо-генеративном граматиком, функционални приступ граматичком опису дат у оквиру конгнитивно лингвистичке теорије, пасивну конструкцију не види искључиво кроз призму форме и у нераскидивом односу са одговарјућим еквивалентом у активу, нити у односу синонимије са истом. Супротно томе, конгнитвнолингвистички приступ граматичком опису, поред формалне компоненте, у опис пасивне конструкције укључује како семантичку, тако и прагматичку компоненту, при чему се овој конструкцији даје велики степен аутономије у односу на одговарајући јој „еквивалент” у активну. Другим ријечима, негира се конструкцијска полисемија, што значи да активна и пасивна конструкција нису изведене из исте дубинске структуре, односно да представљају примјере двију различитих конструкција.

Не умањујући значај трансформационо-генеративне граматике, која је бавећи се питањем језика и људског ума прва на значајнији начин довела у везу однос језика и когниције и на тај начин утрла пут когнитивној лингвистици, сматрамо да би промовисање функционалних приступа опису пасивне конструкције ријешило питање дефинисања и класификације свих оних конструкција које, иако формално не сличе пасиву и немају свој директни еквивалент у активу, ипак на одређен начин представљају семантичке примјере ове конструкције. На овај начин такве конструкције не би више биле маргнинализоване и неправдено искључене из озбиљнијег граматичког разматрања. Сматрамо да би промовиснаје оваквог приступа опису пасивне конструкције довело до промјене дубоко увријеженог начина на који се ова конструкција изучава у образовном систему и допринијело њеном обухватнијем и систематичнијем опису у односу на традиционални формалистички начин њеног представљања. 


\section{ЛИТЕРАТУРА}

Чомски 1957: N. Chomsky, Syntactic Structures, The Hague: Mouton.

Чомски 1965: N. Chomsky, Aspects of the Theory of Synatx, Cambrdige, Massachusets: MIT Press.

Гелд 2006: R. Geld, Konceptualizacija i vidovi konstruiranja značenja, u : Suvremena lingvistika lingvistika 62, 183-211.

Кац и Фодор 1963: Katz J. and J.A. Fodor, The Structure of a Semantic Theory, u: Language 39, 170-210.

Кац и Постал 1964: Katz, J. J. and P. Postal, An Intergrated Theory of Linguistic Description, Cambridge, Massachusets: MIT Press.

Крофт и Круз 2004: Croft W. and D. Cruise, Cognitive Linguistics, Cambridge: Cambridge University Press.

Кујунџић 2014: М. Кујунџић, Утицај трансформационо-генеративне граматике на третман пасива и неким од савремених граматика енглеског језика и монографија о пасиву, у: Радови филозофског факултеma 16, књига 1/2, Пале: Филозофски факултет, 555-574.

Кујунџић 2015: М. Кујунџић, Утицај традиционалних граматицара над третман пасива у савременим граматикама енглеског језика, у: Радови филозофског факултета 17, Пале: Филозофски факултет, 299-321.

Кујунџић 2016: М. Кујунџић, Пасив у језику британске штампе, Пале: Филозофски факултет

Кверк и др. 1985: Quirk et al., A Comprehensive Grammar of the English Language, London: Longman.

Лејкоф и Pос 1978: Lakoff G. and J. R. Ross, Is deep structure necessary?. U: J. D. McCawley (Ed.), Syntax and semantics 7, 159-164.

Лангакер 1987: R.W. Langacker: Foundations of Cognitive Grammar, Vol. 1: Theoretical Prerequisties, Standford, California: Stanford University Press.

Лангакер 2000: R.W. Langacker, Grammar and Conceptualization, Berlin-New York: Mouton de Gruyter.

Свартвик 1966: J. Svartvik, On Voice in the English Verb, The Hague-Paris: Mouton.

Талми 2001: L. Talmy, Toward a Cognitive Semantics, Cambridge, Massachusets: MIT Press.

Тејлор 2002: J. R. Taylor, Cognitive Grammar, Oxford: Oxford University Press. 


\title{
A COGNITIVE SEMANTIC APPROACH TO THE PASSIVE WITHIN THE THEORETICAL FRAMEWORK OF CONSTRUCTION GRAMMAR
}

\begin{abstract}
Summary
In contemporary linguistic literature, same as in the traditional grammars of the English language, as well as in transformational-generative grammar, the passive construction is predominantly defined with respect to its active equivalent from which it is derived through the process of inversion. Such understanding of the passive construction might be held responsible for the fact that many constructions, which on the basis of their form and meaning, could be seen as examples of the passive, are simply neglected since they do not have their direct active equivalents. Such a formalistic approach to the grammatical descripton of syntactic structures has been modified by cognitive linguistics, which, as opposed to the formal approach, put an emphasis on the interaction between syntactic, semantic and pragmatic components. Therefore, the aim of this article is to point out to the possibility of defining the passive construction form the perspective of cognitive linguistics, since such an approach would invest us with a more encompassing perspective of the passive and in this way help us solve the issue of all those neglected and marginalized constructions that have been labeled as 'pseudo- or semi-" passives. In this way we could establish the additional model that, on a semnatic level, would be treated as a subgroup of the passive construction, which would finally influence the change of the way the passive construction has been treated and defined in the contemporary grammars of the English language and consequently thought and presented within the educational system.
\end{abstract}

Maja R. Kujundžić 